CURRENT SOCIOLOGY/LA SOCIOLOGIE CONTEMPORAINE Volume XXI (1973), No. 2: Religious Organization 
EDITOR

Margaret S. Archer

Department of Sociology, University of Warwick

Coventry CV4 7 AL, England

EDITORIAL BOARD

J. Ben-David

Department of Sociology

Hebrew University, Jerusalem

A. Reiss

Department of Sociology

Yale University

A. Cavali

Instituto di Sociologia

Università Padova

K. Svalastoga

Sociologisk Institut

Københavns Universitet

S. Lukes

Balliol College

F. Tenbruk

Oxford

Seminar für Soziologie

Universität Tübingen

ADVISORY BOARD

A. Akinowo

Nigerian Institute of Social and Economic Research

University of Ibadan

S. Bagu

F.L.A.C.S.O.

Santiago, Chile

A. Bujra

Department of Sociology

University of Dar es Salaam

A. Bouhdiba

Department of Sociology

University of Tunis

F. Fukutake

Department of Sociology

University of Tokyo
E. Gellner

London School of Economics and Political Science

University of London

P. Gonzales-Casanova

Instituto de Investigaciones social Ciudad Universitario Mexico

Lê Thành Khôi

U.E.R. de Science de l'Education

Université René Descartes, Paris

R. Mukherjee

Indian Statistical Institute

Calcutta

P. Pieris

U.N. Asian Institute for Economic Development and Planning, Bangkok 
CURRENT SOCIOLOGY / LA SOCIOLOGIE CONTEMPORAINE Volume XXI (1973), No. 2

\section{Religious Organization}

A Trend Report and Bibliography

Prepared for the International Sociological Association under the auspices of the

International Committee for Social Sciences Documentation

by

JAMES A. BECKFORD 


\section{Subscription information}

One year subscription covers a volume of 3 issues:

$\begin{array}{llllll}\text { Institutions, libraries: } & 52 \text { Dutch guilders } & \$ 22 & £ 9.00 & 90 \mathrm{~F} & 52 \mathrm{DM} \\ \text { Individuals, PREPAID: } & \text { 39 Dutch guilders } & \$ 17 & £ 7.00 & 70 \mathrm{~F} & 39 \mathrm{DM}\end{array}$

The Dutch guilder price is definitive

Payment can be made by cheque, bankdraft, moneyorder or Unesco coupons and should accompany orders to ensure rapid handling.

Subscription at regular rate, single or back issues may be ordered through any bookseller or subscription agent, or directly from the publishers, Mouton \& Co.

Subscription orders for Latin America (including Mexico) may be placed with Swets and Zeitlinger, Caixa postal 18.026 - Meier, 20.000 Rio de Janeiro, Brazil, or Swets and Zeitlinger, Casilla correo 10.249 - Katalenic, Lima, Peru.

Individuals may subscribe at the reduced rate for private use only and exclusively with the publishers at the addresses in The Netherlands, France or the U.S.A. Orders at reduced rates will not be billed.

DELIVERY WILL ONLY BE MADE ON RECEIPT OF PAYMENT.

Netherlands

Mouton

P.O.B. 482

NL-2076 The Hague
France

Mouton

7, Rue Dupuytren

F-75006 Paris
U.S.A./Canada

Mouton

c/o Macfarland Company

1716, East Second Street

Scotch Plains, New Jersey 07076

Published with the financial support of Unesco

under the auspices of the

International Sociological Association/Association International de Sociologie.

Cover design by Jurriaan Schrofer

ISBN 9027978514

(C) 1975, Mouton \& Co

Printed in the Netherlands 